\title{
Huck as a Perpetual Outsider: American National Identity in The Adventures of Huckleberry Finn
}

\author{
Daimi Bir Yabancı Olarak Huck: Huckleberry Finn'in Maceraları Adlı \\ Romanda Amerikan Ulusal Kimliği
}

\begin{abstract}
Gökhan ALBAYRAK *
Abstract: Mark Twain's The Adventures of Huckleberry Finn has been regarded as a manifestation of the American exceptionalist myth which has profoundly influenced American national identity. Drawing on this interpretation, this article asserts that Mark Twain's novel not only valorises the ethos of American exceptionalism, but also undermines it. The American exceptionalist perspective is predicated upon the constructed opposition between the Old World and the New World. This American myth is alleged to originate from the American Puritans' belief in their errand into the wilderness and to draw upon the frontier experience. The polarity between civilization and nature established by the American myth corresponds to the clash between culture and savagery that structures Mark Twain's novel. Hence, it provides ground for the discussion of this novel within the context of the American exceptionalist myth. The discussion concentrates on Huck's relationship with his female guardians and his father, and his encounter with Jim and this paper argues that Huck's experience is in accord with the American myth in terms of his flight from the domesticating dynamics of civilization and his venture into the wilderness, whereas his narrative also subverts the American ethos in regard to the confusion of identities and the permeability of boundaries.
\end{abstract}

Keywords: Huckleberry Finn, American Exceptionalism and National Identity

Öz: Twain'in Huckleberry Finn'in Maceraları adlı romanı, Amerikan ulusal kimliğini derinden etkileyen Amerikan istisnacılığı mitinin bir tezahürü olarak görülmüştür. Bu yorumdan yola çıkarak, bu makale bu romanın sadece Amerikan istisnacılığını takdir ve temsil etmekle kalmadığını, aynı zamanda bu söylemin altını oyduğunu da iddia etmektedir. Amerikan istisnacılığı, yeni dünya ve eski dünya arasındaki yapay bir zıtlığa dayanmaktadır. Bu Amerikan mitinin, Amerikalı Püritenlerin yabanıl doğayı düzenleme, evcilleştirme görevine dayanan inançlarından kaynaklandığı ve sınır deneyiminden beslendiği ileri sürülmektedir. Amerikan istisnacılığı miti tarafindan kurulan uygarlık ve doğa arasındaki kutupluluk, Twain'in romanını biçimlendiren kültür ve vahşet arasındaki çatışmaya denk gelmektedir. Bu yüzden, bu romanı Amerikan istisnacıllığı bağlamında okumak ve tartışmak çok verimli olmaktadır. Bu tartışma önce Huck'ın kadın vasileriyle ve babasıyla olan ilişkisine odaklanıp, daha sonra Jim ile olan dostluğuna yoğunlaşmaktadır. Bu çalışma, Huck'ın yaşantısının, medeniyetin uysallaştırıcı dinamiklerinden kaçması ve yabanıl doğaya doğru bir yolcuğu arzu etmesi açısından Amerikan istisnacıllğı ile örtüşürken, diğer taraftan da bu anlatının kimliklerin birbirine karışması ve sınırların geçirgenleşmesi açısından da Amerikan istisnacılığı mitini alt üst ettiğini savunmaktadır.

Anahtar sözcükler: Huckleberry Finn, Amerikan İstisnascıllı̆̆ ve Ulusal Kimliği

* Dr. Ankara Üniversitesi, Yabancı Diller Yüksekokulu, Ankara. galbayrak85@gmail.com, https://orcid.org/00000003-2703-4326 
"All modern American literature” Hemingway (1935) maintains, "comes from one book by Mark Twain called 'Huckleberry Finn"” (22). Regarded as one of the greatest classic novels of American literature and "celebrated as the archetypal American novel” (Jehlen 1995, 93), The Adventures of Huckleberry Finn, first published in the USA in 1885, is credited with inaugurating the modern aesthetic in American literature, for it portrays real American people and uses their real language. Mark Twain inspired other writers to make "literature out of American experience rather than European books" (Railton 2004, 55). :His narrative of the American experience is animated by its defiance of European high culture. Hence, this novel has been interpreted as a commemorative manifestation of American exceptionalism that has been claimed to have shaped American national identity. Huck, who "light[s]out for the Territory ahead of the rest" at the end of the novel (Twain 1948, 405), embodies "the representative American alone in the wilderness - ready to cast off the past and make a new and self-reliant start, depending for his guide on the authority of individual conscience rather than of inherited social convention" (Messent 2007, 114). In accord with this interpretation, this article questions whether this novel that is believed to herald the birth of the American national identity represents the American exceptionalist ethos or it undermines it. The American exceptionalist ethos is predicated upon the distinction drawn between the Old World that stands for the Western European civilization and the New World that is founded by the European Puritan settlers in America and is claimed to have emancipated itself from the preconceptions of the corrupt Old World. The vital defining element of the exceptionalist American identity rests upon the notion that "the United States is distinct from the Old World" (Restad 2015, 3). This paper discusses if the New World genuinely disconnects itself from the legacy of the Old World or if the American exceptionalist perspective maintains this legacy, preserves its mental boundaries and inherits European civilization in order to demonstrate its superiority. This study first concentrates upon Huck's relationship with his female guardians and his father, and then focuses on the encounter between Huck the white boy and Jim the black man, who are both outcasts and "the two main protagonists of the novel" (Messent 2007, 76). This article seeks to figure out if the Western Metaphysical tradition of the Old World, built on "the distinction between mind and body" (Loux 2006, 1), inheres in Huck's relationship with Jim. This paper aims to scrutinize how far the Western Metaphysical binary frame is employed or cancelled out in Huck's relationship with Jim. The aim is also to trace the Western Metaphysical association of the body/nature/female versus the mind/civilization/male in Huck and Jim's devotion to one another and is specifically interested in how the notion of paternity fashioned by the Metaphysical tradition is challenged, redefined and refashioned in the relationship between Jim and Huck; it questions how fatherhood and faith in God are interrelated in the mind frame of the Old World, and whether Huck's encounter with Jim is related to this mind-frame or if it subverts it.

American exceptionalism has been considered the crucial defining element of American national identity. Spanos (2008) points out that American exceptionalism refers to

an ontological interpretation of the American national identity whose
origins lay in the American Puritans' belief that their exodus from the
Old World and their "errand in the wilderness" of the New was, on the
prefigurative analogy of the Old Testament Israelites, divinely or
transcendentally ordained and which became hegemonic in the course of
American history with its secularization as Manifest Destiny in the
middle of nineteenth century and as the end of history and the advent of
the New World Order at the end of the twentieth century (188).

The American exceptionalist perspective is predicated on the idea that the American identity discards the over-civilization of the Old World, the Western European legacy, and it urges one 
to roam in the wilderness so as to tame it and to have an unmediated relation to nature. Spanos (2008) refers to the American Puritans' "desire to rationalize the wilderness in majorem gloriam Dei, to 'clear,' to 'settle,' and 'improve' the wilderness” (196). An attunement to uncultivated nature leads to a break from the decontaminating bondage and sterilizing vestiges of civilization. Accordingly, the American national identity is founded on the opposition between civilization and wilderness. Spanos refers to Bercovitch's American Jeremiad, which describes the origins of the American Puritans' errand in the wilderness, in order to explain the distinction that has been constructed between the Old World and the New World. According to Bercovitch, the American jeremiad points to the American/Puritan calling and constitutes the birth of the American national identity. The American Puritans' belief is based on 'the ritual of a culture on an errand - which is to say, a culture based on a faith in progress"; this belief disposes of "the Old World ideals of stasis for a New World vision of the future"; the function of this ritual is to forge "a climate of anxiety that helped release 'progressivist' energies required for the success of the venture" (Bercovitch 1978, 23). This vision of the New World renders the American character restless and yearning to go beyond boundaries.

According to this conception of the New World, the Old World represents a civilization that "had become 'old,' 'decadent,' 'sterile,' 'impotent,' 'tyrannical,' 'collective,' 'immobile,' 'effete,' 'profane' that is, overcivilized" while the New World stands for "a civilized world that was 'new,' 'creative,' 'manly,' 'productive,' 'free,' 'individualist,' 'kinetic,' 'progressive,' 'godly'” (Spanos 2008, 190). Hence, the Old World is portrayed as a corrupt, impotent, feminized old man, whereas the New World is regarded as a virile, forward-thrusting young man who is full of vitality and youthfulness. This fabricated distinction is based upon binary oppositions and these oppositions are gendered in the sense that the Old World is associated with the feminine whereas the New World is connected with the masculine. Spanos (2008) also notes that this crucial distinction that is claimed to have founded the American national identity must be interpreted "in the context of the threat posed by the settled or sedentary life - the domesticating and familiarizing dynamics of civilization - to the youthful, virile, and creative energies" (190). Spanos (2008) also reminds us that these energies that the American exceptional ethos valorizes are "precisely the characteristics the early [Puritan] settlers invoked to distinguish themselves from the Old World" (190). This foundational narrative is reflected in the prevalent themes of American literature: the stifling and sterilizing civilization and, in response to this, the desire to run away into the uncultivated nature (Jehlen 1995, 98).

Spanos (2008) further emphasizes that this inaugural moment of the American exceptionalist ethos must be seen in the context of the American notion of the frontier: "that forward-moving boundary line between wilderness and settlement, the unfamiliar and the familiar, anxiety and complacency, distrust and confidence, violence and peace, 'them' (an enemy) and 'us,' that became in the future the sine qua non of rejuvenating American civilization and the exceptionalist American national identity" (190). The American self is envisioned as being uneasy in the realm of the known and the identifiable and therefore desiring to venture into the domain of the unknown, the unfathomable, the uncultivated. The American Puritans' need for "a perpetual frontier between wilderness and civilization" constitutes an exceptional New World that is different from "an Old World that had run out of frontiers" (Spanos 2008, 197). This perpetually open frontier is believed to revitalize the American spirit. Spanos (2008) also refers to Frederick Jackson Turner, the founder of the theory that "the frontier was the determining factor in the shaping of American history and the American national identity" (211). The construction of terra incognita that lies beyond the confined borders of the settled and sedentary life is what reinvigorates the American identity.

The American exceptionalist ethos has a "metaphysical basis" (Spanos 2008, 189). 
Although the American identity claims to have abandoned the heritage of the Old World, the American understanding of the discrepancy between civilization and wilderness shows the American identity defines itself by means of the binary frame of the Western Metaphysical tradition which is built upon such binary oppositions as white versus black, male versus female, civilization versus wilderness, and mind versus body. The Western Metaphysical tradition seeks to maintain its existence through privileging the white over the black, and the mind over the body. This perspective associates the body with the female principle while it associates the mind with the male principle. Similarly, nature stands for the female/body whereas civilization stands for the male/mind. The American exceptionalist ethos considers that the high-civilization of the Old World is corrupt and it prevents one from having an unmediated relation to nature. The American perspective posits that the Old World does not allow one to have an immediate sense of being in the world, yet forces him/her to experience life through preconceived notions and established codes. Moreover, the American exceptionalist perspective finds that the overcivilization of the Old World feminizes man. Therefore, the notion of civilization, which is conventionally identified with the masculine principle according to the founding fathers of the Old World, comes to be associated with the feminine principle in the New World. Accordingly, the American identity, once it is stripped of its European trappings and freed from the sterilizing bondage of civilization, is believed to reclaim its masculine authenticity by means of roaming the wilderness and domesticating it like a man seeking to tame wild nature in primordial times, an age-old conception of manliness and virility perpetuated by the patriarchal foundations of the civilization of the Old World. Even though the American identity is allegedly distanced from the legacy of the Old World, its relation to the wilderness and its attempt to bring it under control and domesticate it shows that it is still founded on the binary frame of the Old World. Viewing the native inhabitants of America as savages and trying to destroy them, taming the wilderness and imposing their own understanding of civilization on it, is an extension of European imperialism, which is similarly enacted in the Robinson Crusoe myth that certainly resonates with Huckleberry Finn's adventures. Furthermore, the Western Metaphysical tradition associates nature with the mother and the maternal body while it associates civilization with the father, the paternal spirit. This metaphysical perspective is found in the European understanding of being in the world, and also the perception of the other world in religious terms. The European understanding of being in the world mostly descends from the dichotomy between the self and the other; it oppressively privileges the self over the other, and demonizes the latter. Also, the European understanding of the religious faith is built on the Western Metaphysical opposition between the body and the mother versus the mind (spirit) and the father. To recap, Spanos, who refers to "the antimetaphysical discourses" of Heidegger, Derrida, Lyotard, Spivak, Bhabha, Althusser and Deleuze and Guattari (Spanos 2008, 45), points to "the metaphysical ground of the founding American mythology" (Spanos 2008, 282).

These binary oppositions that constitute the Western Metaphysical tradition correspond to the oppositions that are inherent in the ideology of the American exceptionalist ethos. The boundaries established by the American exceptionalist ethos between "“savagery' and 'civilization,' threatening forest and secure settlement, diabolic enemies and supportive friends, the uncertainty of the strange and confidence of the familiar" (Spanos 2008, 196) resonate with the oppositions that structure Huckleberry Finn between "black and white, instinct and impulse and social belonging and learned language, river and shore, raft and permanent 'home', civilization and wilderness, child and adulthood, male and female, slavery and freedom" (Messent 2007, 114). Since these oppositions are very similar, it provides a fertile avenue to explore Huckleberry Finn in respect to the American exceptionalist ethos.

Huck's relationship with his female guardian and his desire to discard the sterilizing and civilizing influence of this relationship seems to accord with the American exceptionalist myth 
that urges the American self to venture into the wilderness. Huck's discomfort with civilization and his impatience with its restraints is similar to the American repudiation of the overcivilization of the Old World. As an outsider "in flight from the authority of guardian and father" (Messent 2007, 77), he is uncomfortably poised within society. Being in Widow Douglas's care corresponds for Huck to being restricted by civilization:

The Widow Douglas she took me for her son, and allowed she would civilize me; but it was rough living in the house all the time, considering how dismal regular and decent the widow was in her all ways; and so when I couldn't stand it no longer I lit out. I got into my old rags and my sugar-hogshead again, and was free and satisfied (Twain 1948, 1-2).

Huck refuses to be civilized by Widow Douglas. He wishes to escape his "acculturation" (Railton 2004, 63). Being a free spirit, he avoids being habituated to a fixed and settled community. Free from the frustrating constrictions of genteel respectability, he desires to wear his old rags, go into the wild nature, sail along the river. He is not "at ease with this new domestic world and the widow's disciplinary regime” (Messent 2007, 75). Huck seeks to abandon civilization, which makes him "sweat and sweat, and feel all cramped up" (Twain 1948, 2), and refashion himself in a world of his own where he does not feel smothered. Huck's story can be read as a romantic quest for freedom. This narrative of escape describes the ideal of individual freedom and restlessness which is "fundamental to the nation's founding philosophy" (Jehlen 1995, 97). The notion that civilization imprisons matches well with the inauguration of the American national psyche.

At this point, one also needs to ask who initiates his journey out of the civilization, if he can really free himself from the civilization, and if the civilization he flees intrudes upon his quest, and overshadows his journey. Huck is not thrilled with his new life of cleanliness, manners, church, and school. Fiedler (2004) speaks of "the threat always lurking beneath matriarchal tenderness: the rigid piety, the petty discipline, the belief in soap” (30). This matriarchal tenderness is associated with the sterilizing and domesticating dynamics of civilization in the context of the American exceptionalist ethos. In his journey to individual freedom, Huck escapes the feminine guardians of the civilization owing to his father. Huck's brutish, drunken father, Pap, reappears in town and demands Huck's money. Outraged when the Widow Douglas warns him to stay away from her house, Pap kidnaps Huck and holds him in a cabin across the river from St. Petersburg. Thus, Huck's freedom from civil life is triggered by his own father who "removes him from the claustrophobic environment of the town" (Wieck 2007, 49). Disconnected from the matriarchal world of Miss Watson, he feels he is granted a special immunity from "the codes of the mothers" (Fiedler 2004, 30). Miss Watson stands for the feminine principle that adopts Huck and tries to domesticate the boy. The civilized, settled and sedentary life is associated with the feminine principle. On the other hand, Pap represents the emancipation from the civilization of the Old World even though he is drunken and brutish. The opposition between these two forces in the persons of Miss Watson and Pap is revealed in Huck's following remark: “I didn't want to go to school much before, but I reckoned I'd go now to spite pap" (Twain 1948, 32). Hence, the feminine principle that represents the effete civilization of the Old World is situated in opposition to the masculine principle that embodies the virile, manly and youthful New World: the surrogate mother versus the biological father. Being kidnapped by his father liberates Huck from the force of civilization which suffocates him. He comes to enjoy his life with Pap outside of the conventions of the society:

It was kind of lazy and jolly, laying off comfortably all day, smoking and fishing, and no books nor study. Two months or more run along, and my 
clothes got to be all rags and dirt, and I didn't see how I'd ever got to like it so well at the widow's, where you had to wash, and eat on a plate, and comb up, and go to bed and get up regular, and be forever bothering over a book, and have old Miss Watson pecking at you all the time. I didn't want to go back no more. I had stopped cussing, because the widow didn't like it; but now I took to it again because pap hadn't no objections. It was pretty good times up in the woods there, take it all around (Twain 1948, 33).

Huck is free from Miss Watson's civilizing tendency. He enjoys being cut off from the conventions of the social life: "he is incapable of remaining inside the respectable community; he is actually happy when Pap carries him off" (Fiedler 2004, 31). He seems to have achieved independence from the codes of the civilization. One may argue that he is no longer indoctrinated by the imperatives of the civil life.

However, Huck has not embarked on his quest for freedom, yet. His escape from the civilization represented in the person of Miss Watson is realized because he has been kidnapped by his father. Huck is far from liberation because he is under his father's authority. Whenever Pap goes out, he locks Huck in the cabin, and when he returns home drunk, he beats the boy:

But by and by pap got too handy with his hick'ry, and I couldn't stand it. I was all over welts. He got to going away so much, too, and locking me in. Once he locked me in and was gone three days. It was dreadful lonesome. I judged he had got drownded, and I wasn't ever going to get out any more. I was scared. I made up my mind I would fix up some way to leave there (Twain 1948, 33-4).

Huck is not completely free. He is disconnected from Miss Watson's attempts at civilizing him, yet he is captured by his brutal father. Tired of his confinement and fearing that the beatings will worsen, Huck escapes from Pap by faking his own death. Huck refuses to be dominated by his father. He embarks on a real quest for freedom once he repudiates his father's authority through his feigned decease. Being imprisoned by his father is more threatening for his freedom: "The only release is escape, flight, and effacement of the identity through which both town and Pap oppress him; he can resume autonomy only by assuming "death" for his name" (Trachtenberg 1991, 87-8). In order not to be a besieged child, Huck must pretend to be dead. He must be free of parental supervision so as to claim a wild, unruly state of existence which he cherishes. This desire for unmitigated freedom requires him to fake his death and thus to disguise himself; this undermines "any notion of fixed self" (Messent 2007, 79). In order to be free and to escape constraining social bonds, Huck assumes a fluid self. This fluidity, which is metaphorically represented by the river Mississippi, allows him to avoid being pinned down on the wall by the restraints of civilization, and thus enables him to journey into the wilderness beyond the borders of the community, which is in accord with the restless American self that is celebrated by the American exceptionalist ethos.

Huck's flight from his father's oppression should be considered in the light of the conventional understanding of paternity by the Old World. One may claim that the Western Metaphysical tradition stipulates in accordance with the binary frame that the child submits to the father's authority. This filial submission to paternal authority is evident in the patriarchal foundations of the Old World, especially in the glorification of monarchies. It is reflected in the monarchies of the Old Word where kings are regarded as the fathers of the nations. The fatherson frame also inheres in the religious faith of the Old World; the father image is traditionally associated with the god image; fathers are deified, or revered as the agents of the divine will, as 
the foundational myths of the Western civilization attest. Therefore, one can argue that the religious and monarchic legacy of the Old World is closely related with the issue of fatherhood. From a Freudian perspective, the Western Metaphysical tradition is built on ancient myths about the father-son encounters; the myth of Oedipus is one of the primary ones. Ancient Greece, on which the civilization of the Old World is claimed to be predicated, provides one with many mythological stories which are about the oppressive, castrating father figures and the submissive or rebellious sons. Traditionally the father-son relationship is never free of oedipal struggle. Huck's relationship with his father is reminiscent of the ancient myths which are about the authoritative father figures and the sons who are expected to submit to the father's authority. Huck refuses to be dominated by paternal authority. His escape from his father's oppression is only realized through his fake death. His fake death is symbolic; it is a manifestation of the fact that he must die in order to be born again in metaphorical terms. He discards the identity of a docile son who is oppressed by his father, and sets out to forge a new liberated identity. Once Huck emancipates himself from his father's oppression, he sets out to refashion himself. He now embarks on a real quest to be "a self-determining subject" (Messent 2007, 78). This repudiation of the paternal oppression is suggestive of the birth of the American national psyche and its valorization of individual freedom.

That Huck dissociates himself from the confinement imposed on him by his father does not make him a completely liberated person. His refutation of his father's authority that stems from the Western hegemonic discourse built on the dichotomy between the oppressor and the oppressed is merely one step taken on the road to the freedom. Huck is metaphorically an orphan as he is stripped of his identity shaped by the dominant discourse which privileges the father's authority. His quest is an unconscious attempt to severe himself from the ideology that enslaves him. He hides on Jackson's Island in the middle of the Mississippi River and watches the townspeople search the river for his body. During his stay on the island he assumes the characteristics of the dominant discourse. As he reinvents a new self, he reinvents the world. After he stages his own death, Huck arrives on the island believing that he will be able to abandon civilization and forge a new identity for himself. However, Huck unconsciously holds on to the values of the civilization he has sought to flee. The image of the virgin land invokes the American exceptionalist ideology that urges one to domesticate and cultivate the unspoiled, uncultivated land, and impose civilization on it. The dominant ideology that perpetuates the American exceptionalist myth intrudes upon Huck's quest for freedom. The civilization that he flees revisits him: "And so for three days and nights. No differences-just the same thing. But the next day I went exploring around down through the island. I was boss of it; it all belonged to me, so to say, and I wanted to know all about it” (Twain 1948, 54-5). Like a new-world settler, he claims to be the boss of the island: "Huck has latched on to one of the most prominent American Dreams [...] the dream of domination in the guise of creating a new world, or settling a new land" (Kravitz 2007, 171). Huck does not realize that he reenacts his ancestors' hegemonic behavior when he claims to be the boss of the island. One can detect the notion of America's errand into the wilderness in Huck's approach to the island. The civilization which Huck disconnects himself from threatens to encroach upon him. Huck's claim to be the boss of the island shows that he is still indoctrinated by the prevalent ideology which he challenges through his escape from Miss Watson's attempt at civilizing him, and his flight from his father's oppression.

After a few days on the island, he encounters Jim, one of Miss Watson's slaves. Huck and Jim team up, despite Huck's uncertainty about the legality or morality of helping a runaway slave. Huck's encounter with Jim is of central importance, as it shows how far Huck undermines the American exceptionalist ethos. Huck's relationship with Jim challenges the foundations of the American exceptionalist perspective. Also, Huck's relationship with Jim is subversive in the 
sense that it turns upside down the binary frame of the Western Metaphysical tradition: "it is the mixing of black and white voices in a high-brow or low-brow cultural attempt to discover the similarity rather than the differences between oppressor and oppressed.” (Kravitz 2007, 188). In Huck's relationship with Jim, the white is no longer the master; the black is no longer the slave, either. On Jackson's Island, "the voices of these two marginal figures are allowed to speak freely and [...] openly and in overall harmony with one another" (Messent 2007, 86). This alliance forged by free individuals threatens to shatter the boundary between the self and the other, and by extension, the borders between other binary oppositions such as savagery and civilization, diabolic foes and nurturing friends, upon which the American exceptionalist perspective is built. The American exceptionalist ethos stretches the boundary between civilization and wilderness as it urges the American self to clear, settle and thus dominate the wilderness. However, that boundaries become permeable threatens to subvert the American ethos that seeks to consolidate the distinction between what is American and what stands outside this national identity.

Nonetheless, it is misleading to consider Huck's relationship with Jim is completely free from the norms of the American exceptionalist ethos. The codes of the American exceptionalist myth occasionally resurface in Huck's encounter with Jim. Accordingly, Messent (2007) argues that the "raft is not a place without conflict" and adds that it is "a fragile space, mown down by a steamboat, colonized by the king and the duke, floating downriver ever deeper into slave territory" (86). This paper's primary concern is to show that, on the one hand, a loving and caring relationship makes Huck and Jim transcend the imperatives of the American hegemony, while, on the other hand, some vestiges of the American exceptionalist ethos still remain.

The main reason why Huck and Jim manage to have a loving and caring relationship beyond the confined borders of the dominant ideology is that both of them are cast away: "the sympathy between the boy outcast from society and the negro fugitive from the injustice of society" (Eliot 2004, 20). Both Huck and Jim are orphans; Huck is an orphan in the sense that he escapes from his parent and the civilization that attempts to adopt him; Jim is an orphan in the way that he is stripped of his genuine ancestral roots as a slave and seen as an intimidating other in a society where he is oppressed and ostracized. They "step outside the borders of the everyday southwestern community, alone together in nature, able to 'feel mighty free and easy and comfortable' there” (Messent 2007, 86). These two orphans sympathize with each other because they flee the same civilization which is oppressive towards them both: "the irreparable breach between black and white seems healed by love" (Fiedler 2004, 34). They are in search of a new frontier where they are not oppressed by civilization. Huck is in a quest as he seeks to transcend the civilization which suffocates him. Similarly, Jim is in a quest since he seeks to liberate himself from the same civilization which enslaves him. Like Jim, Huck is also enslaved by the civilization. They develop an intimacy in a new territory of becoming outside the boundaries of the hegemonic discourse of the society.

Huck's relationship with Jim can be considered as a father-son relationship: "a father-son bond ripens on the flux of the river" (Obenzinger 2005, 404). Huck refuses to be dominated by his murderous father. Jim becomes a surrogate father for Huck: "the most powerful passages of the novel may be found in the opening sequences where Huck awaits the arrival of his father, escapes him, and rushes off in a blaze of ambivalence with his alternate father, Jim" (Segal 2007, 28). The chapters where Huck encounters his brutal father indicate a son's turbulent struggle against intimacy with a threatening father. Segal (2007) points out that the language of the opening chapters of the novel is indicative of the struggle between father and son (29). The unconscious rivalry between father and son is manifested when Huck says that he would like to go to school just to spite his father although he does not enjoy going to school; he stands up against his uneducated father by means of showing off that he can read. Segal (2007) argues that 
Huck's confrontation with his father is "about oedipal struggle” (33). Huck wants to be his own master in accordance with the pioneering American spirit; he refuses to be oppressed by his father's authority. The rejection of the father's authority is related to the American refutation of the Old World's civilization. The image of the oppressive father is a legacy of the Old World. Once the American identity discards the Old World's civilization, it also discards the definition of despotic paternity perpetuated by that civilization. Therefore, the American spirit is to redefine the concept of fatherhood. The oppressive father figure represented by Huck's father is in contrast to the free-spirited American who defies the corrupt concepts of the Old World such as monarchy and despotic paternity, concepts that are shaped according to the religious association of god, king and father.

Huck's relationship with Jim shows the possibility of a real reconciliation with the father figure outside the boundaries of the patriarchal civilization that entails the submission of the son to the father's authority. Huck's encounter with paternal figures throughout the novel, especially with Jim as the surrogate parent, indicates the redemptive transformation of the father-son relationship into a loving and caring one: "Father relationships, so fraught with fear and loathing, can be changed into a more peaceful intimacy" (Segal 2007, 37). It is generally argued that Huckleberry Finn is a story where Huck adopts a series of fathers to father him; he wishes that his biological father were dead, yet he also wishes to find a father figure in Jim. Furthermore, Segal (2007) claims that "life without father is impossible for Huck Finn; both Huck and his narrative are constituted by the race from and inevitable attraction to the paternal" (39). Huck flees from his murderous father who represents the castrating, tyrannical, old and impotent father figure of the civilization of the Old World; however, he feels attracted to the father figure in Jim, a reconfiguration of the paternal outside the boundaries of the culture of the Old World. Huck unconsciously cherishes a father figure who is not forged according to the imperatives of the imperialistic culture of the Old World. Bloom (2007) points out that "[w]ithout a family, yet with a murderous father always apt to turn up again, Huck perpetually experiences a primal loneliness that he both welcomes and dreads" (2). Huck desires a freedom from a deathly father; he evades the brutal father. Without the paternal authority configured by the civilization of the Old World, Huck is made to feel lonely:

When it was dark I set by my camp-fire smoking, and feeling pretty wellsatisfied; but by and by it got sort of lonesome, and so I went and set on the bank and listened to the current swashing along, and counted the stars and drift-logs and rafts that come down, and then went to bed; there ain't no better way to put in time when you are lonesome; you can't stay so, you soon get over it (Twain 1948, 54).

Huck's loneliness results from the fact that he is disrobed of his identity shaped by the dominant discourse. His solitude stems from his refusal to be indoctrinated by the civilization; he flees civilization; he disowns it; in other words, he orphans himself. As much as he dislikes loneliness, he also craves solitude, freedom from the murderous father. He refuses to be dominated by the brutal father; he wants to be his own master. Bloom (2004) points out that Huck represents "the American religion of self-reliance" (4). Huck does not want to be injured by the authority of the father; his desire to master himself springs from the American rejection of the culture of the Old World which the American exceptionalist ethos asserts privileges the authoritative, oppressive, monarchic regime over the individualistic, liberating democratic system. Huck's refusal to be dominated by the oppressive father is in accord with the American spirit that discards Western civilization that is built on the supremacy of the oppressor over the oppressed. Huck enjoys the independence of the vagabond. Fiedler (2004) calls him "the uncommitted idler" (28). Huck alienates himself from the stifling civilization which tries to 
inscribe him against his sense of freedom. He is always in flight: "to be himself Huck must never cease moving, never learn to belong” (Fiedler 2004, 33). Huck’s restlessness and moving on the fringes of society is fundamental to the American national identity; he lights out for the territories, which invokes the American myth that urges one to move further. Huck's narrative is a subversive one; he is always in motion; he refuses to be stabilized and tamed by the civilization; his understanding is that "he can never fit into society" (Pinsker 2007, 73). His urge to go away from civilization is what reinvigorates him and resuscitates his sense of being.

Huck's growing bond with Jim can be interpreted as a form of pre-discursive intimacy that is developed beyond the grasp of the dominant discourse. Their relationship can be considered to be immersed in feelings which are beyond the configuration of the dominant culture. Through his escape from the matriarchal influence of Miss Watson, Huck goes back to a world of nature which is cut off from the imperatives of the dominant culture. The harmony between Huck and Jim is realized through their loving and caring relationship; they entrust themselves to the river which turns out to be the symbol of an existence uncontaminated by the codes of the hegemonic discourse: "on the raft the two can sit naked, their legs dangling in the water, enjoying the nearsilences" (Messent 2007, 86). Huck's childhood as a stage in human life can be considered as a safe haven where one is not yet inscribed by the dominant ideology. Fiedler (1991) argues that Huck's life on the raft with Jim represents "the regressiveness of American life, [...] its implacable nostalgia for the infantile” (40). Fiedler mentions the mythic boyhood of America. The infantile is viewed as the time and space of one's life where one is free from the oppressiveness of civilization. During the mythic boyhood one can enjoy the liberty of being un-indoctrinated by the dominant culture. Fiedler (1991) thinks that what D. H. Lawrence says about the Cooper novels is also true for Huck's life on the raft with Jim: "the kid's Utopia: the absolute wilderness in which the stuffiness of home yields to the wigwam" (41). This utopian vision points to the venture "from the stifling house to a stimulating outside space" (Doyno 2005, 388). Fiedler (1991) considers that Huck's life on the raft with Jim represents "the American dream of isolation afloat” (42). Huck's life on the raft, "an idyllic home” (Jehlen 1995, 98), is fundamental to the American experience of discarding the corrupt European civilization; once the civilization of the Old World is discarded, one encounters the mythic infancy prior to one's being cultivated and acculturated by the dominant discourse. This idyllic narrative of boyhood is a manifestation of "the novel's debt to a Romantic tradition of unfettered individualism (the dream of free and autonomous selfhood)" (Messent 2007, 79). The attunement to the Romantic notion of unbridled freedom also demonstrates that the American spirit of restlessness invokes the European Romantic tradition of the Old World. This Romantic tradition of the Old World is characterized by "a striving for the infinite" and a refusal to yield to limitations (Abrams 2000, 14). This Romantic longing for unfettered freedom and the desire to go beyond the limits resonate with the American myth. Besides, the nostalgia for the infantile may seem to be at odds with the American exceptionalist perspective that valorizes manliness and virility. However, this Romantic yearning for a pre-discursive and pre-civilized being in the world, opens a new space where the American self, being restless and always on the move, defines itself and rejuvenates the American myth. The pre-discursive sense of being is rediscovered when the dominant discourse is challenged and abandoned. Fiedler (1991) argues that Huck's relationship to Jim represents "a national myth of masculine love” and it is immune to lust; it is "a chaste male love" (39). In opposition to Fiedler, Marx (1991) argues that Huck and Jim are "devoted to the idea of brotherhood" (54). Also, Schmitz (1991) views Jim as "a brotherly father figure" (102). What is significant about Huck's bond with Jim is that a white boy and a black man can genuinely love and care for each other rather than the former destroying and oppressing the latter once they are stripped of their identities which are shaped by the repressive discourse. 
Their unmediated relationship and attunement to nature and their unconditioned love for each other are fundamental to Huck's narrative. Their yearning for freedom enables them to unearth the true spirit and the loving kindness of human beings; a deformed conscience is discarded and a sound heart is found, as the title of Henry Nash Smith's article suggests (1991, 61). "Jim's true and full humanity" is disclosed in "his one-to-one relationship with Huck on the raft" (Messent 2007, 84). Jim appears as generous, selfless and affectionate; the raft offers "a space outside the slave-owning society" (Railton 2004, 62). Huck and Jim enjoy a selfgenerated liberation from moral depravity. Trachtenberg (1991) points out that Huck and Jim indulge in "the pleasure of a precivilized [...] state of nature" (91). The pre-civilized state of nature is what the American identity is provided with once it discards the decayed civilization of the Old World. Schmitz (1991) speaks of the American rediscovery of the pre-discursive self: "What lies coiled in the child is the aboriginal self, an effortless beauty that mocks the repressed, fiercely civilized adult" (101). Once Huck attains the freedom of spirit of the aboriginal self in the child, "the unregenerate poetic child" revives in his body and he becomes "sensitive to the mystery of being in the world" (Schmitz 1991, 100). The poetic child is revealed in the following lines from the novel:

This second night we run between seven and eight hours, with a current
that was making over four mile an hour. We catched fish and talked, and
we took a swim now and then to keep off sleepiness. It was solemn,
drifting down the big, still river, laying on our backs looking up at the
stars, and we didn't ever feel like talking loud, and it wasn't often that
we laughed-only a little kind of a low chuckle. We had mighty good
weather as a general thing, and nothing ever happened to us at all-that
night, nor the next, not the next (Twain 1948,90).

The poetic self emerges in the child that is not fiercely repressed by civilization. Huck and Jim experience an unmediated relationship to nature. Marx (1991) speaks of Huck's experience as a boy's idyll: "the enchanting image of the raft's unhurried drift with the river" (51). In opposition to Miss Watson's home-spun piety, Huck discovers a sublime sense of being one with nature.

It would be misleading to think that Huck's life on the raft with Jim is just a picture of idealized idyllic existence where they rediscover the true meaning of being alive in a world of nature uncontaminated by civilization. It is still true that they challenge the dominant discourse and discard the imperatives of the dominant ideology when Huck is resolved to help Jim out of slavery at the expense of going to hell, and he takes the heed of his sound heart against the deformed conscience of the dominant hegemony. Messent (2007) points out that "Huck's decision to choose hell rather than to allow Jim back into Miss Watson's hands (for many critics, the climax of the book)" can be regarded as "an act of individual moral responsibility that counters any tendencies of the larger social environment to condition and shape his actions" (78). Nevertheless, it is also true that the civilization that they flee intrudes upon their friendship. Their life on the raft down the river is based on the mythic imagination of the American identity refashioned as a result of its rejection of the culture of the Old World. Twain is also a realist and Huckleberry Finn is "a realist text" (Messent 2007, 77); he knows that their idyllic existence is impossible to realize in this specific time and space before the Civil War. Fiedler (1991) points out that Huck and Jim's flight from the imprisoning society is only a dream in the antebellum society: "the fugitive slave and the no-account boy lying side by side on the raft born by the endless river towards an impossible escape" (40). Accordingly, Fiedler (1991) believes that their experience on the raft beyond the grasp of civilization invokes a dream: "the passage in and out of darkness and river mist, the constant confusion of identities, the sudden intrusions into alien violences without past or future, give the whole work for all its 
carefully observed detail, the texture of a dream” (41). Twain's narrative also symbolically refers to the fact that their mythical pre-civilized life on the raft is a dream; their idyllic experience is interrupted by the twists in the plots. The chapters where they are not drifting along the river but are on land undercut their ideal mythical life on the raft. Even the fog that separates them can be considered as a realistic element that encroaches upon the mythic life outside the boundaries of the indoctrinating civilization.

Huck's utopian relationship with Jim shows that they are devoted to one another and they care for each other. Nonetheless, Huck's relationship with Jim also has some darker sides; the civilization that they flee intrudes on their relationship. Huck has liberal tolerance for Jim, yet he does not have a respect for Jim as a singular human being. Jim becomes a commodity for Tom's pleasure when Tom decides to help Jim escape from slavery in a way that he plans to carry it out in imitation of romantic adventures he reads about a lot in books. They see him as part of a game and the source of their entertainment; they subject Jim to "acute physical discomfort and pain” (Messent 2007, 83). Huck does not resist when Tom stages Jim's escape in such a ridiculous way. Jim is reduced to an object that they can manipulate:

He [Tom] said it was the best fun he ever had in his life, and the most intellectual; and said if he only could see his way to it we would keep it up all the rest of our lives and leave Jim to our children to get out; for he believed Jim would come to like it better and better the more he got used to it. He said that in that way it could be strung out to as much as eighty year, and would be the best time on record. And he said it would make us all celebrated that had a hand in it (Twain 1948, 345).

Thus, Jim is reduced to a plaything for Tom and Huck does not react to Tom's staging Jim's escape in such a way.

In conclusion, this paper exclusively deals with the American exceptionalist myth, which is only one aspect, therefore, one interpretation of the American identity, which is not monolithic, but diverse, multiple and multifaceted. This study concludes that Huck's quest for freedom, his discomfort with culture, his flight from civilization indicates the American identity in him from the perspective of the American exceptionalist ethos. When he is adopted by Miss Watson, the pull of social conventions and codes is overwhelming for him; the fear of becoming civilized is intimidating for Huck. When he is kidnapped by his father, he is happy to have fled the civilizing force that Miss Watson seeks to impose on him. He enjoys the comfort of living with his father because he rejects the claims that consecrate work, duty, decency, regular life, home and cleanliness. Later on, when his father becomes an actual danger to Huck's existence, he is willing to go against his father's authority. Huck escapes from the confinement imposed upon him by his father by means of his pretended suicide. He is unable to accommodate himself to certain situations which require him to submit himself to an adult authority. When he stays on Jackson's Island, he assumes the American attribute of errand into the wilderness. Huck partakes of this ideology when he claims to be the boss of the island. Then, his encounter with Jim opens up a new sphere of existence for him; the two outcasts embark upon a quest into virgin territory together. They begin to experience an idyllic life on the raft drifting down the river; their existence is relatively unmediated by the imperatives of the civilization they challenge. The sphere of the river is relatively uncontaminated by the civilization they flee. Huck sympathizes with Jim as they are both in flight from confinement and imprisonment. In his relation to Jim, Huck represents an image of wise innocence of natural man achieving independence from a morally depraved society, especially when he decides to help Jim escape out of slavery: "morally sensitive, he discards the moral code" of the dominant ideology in order to help Jim gain his freedom (Trilling 2004, 10). This alliance forged by free individuals shows 
that Twain's novel also undermines the American exceptionalist perspective by means of collapsing boundaries and intermingling identities. Realism resurfaces and the idyllic interlude ends. Freedom remains an elusive illusion. Accordingly, Bloom (2004) argues that "the book is not just about freedom, but about the limits of freedom" (2). At the end of the novel, Huck sets out for the frontier, for "terra incognita” (Wieck 2007, 53): "But I reckon I got to light out for the territory ahead of the rest, because Aunt Sally she's going to adopt me and sivilize me, and I can't stand it. I been there before" (Twain 1948, 405). This "breaking-off of contact with his immediate world is a final measure of his social alienation" and this ending can be regarded as "that paradigmatic American move to a new and unspoilt landscape" (Messent 2007, 81). Huck's lighting out into the West is a manifestation of Twain's revitalization of the myth on which the American exceptionalist ethos is built: "that by going west, into a new world, humanity can break the chains that have historically imprisoned them" (Railton 2004, 63). Thus, Twain reaffirms the Romantic belief in the possibility of going into the wilderness as a means of forging a new self and a new world outside the corrupt realms of society and history; he glorifies the promise of individual freedom. This promise draws on the mobilizing power of the American exceptionalist ethos. 


\section{REFERENCES}

Abrams M. H. (2000). “The Romantic Period”. Eds. M. H. Abrams \& S. Greenblatt, The Norton Anthology of English Literature. New York (2000) 1-21.

Bercovitch S. (1978). The American Jeremiad. Madison 1978.

Bloom H. (2004). "Introduction". Ed. H. Bloom, Bloom's Major Literary Characters: Huck Finn. Philadelphia (2004) 1-4.

Bloom H. (2007). “Introduction”. Ed. H. Bloom, Bloom's Modern Critical Interpretations: Mark Twain's Huckleberry Finn. New York (2007) 1-6.

Doyno V. (2005). "Plotting and Narrating "Huck"”. Eds. P. Messent \& L. J. Budd, A Companion to Mark Twain. Malden (2005) 387-400.

Eliot T. S. (2004). “An Introduction to Huckleberry Finn”. Ed. H. Bloom. Bloom's Major Literary Characters: Huck Finn. Philadelphia (2004) 17-24.

Fiedler L. A. (2004). "Huckleberry Finn: Faust in the Eden of Childhood”. Ed. H. Bloom, Bloom's Major Literary Characters: Huck Finn. Philadelphia (2004) 5-40.

Fiedler L. A. (1991). “Come Back to the Raft Ag'in, Huck Honey!”. Ed. L. Champion, The Critical Response to Mark Twain's Huckleberry Finn. Westport, CT. (1991) 39-43.

Hemingway E. (1935). The Green Hills of Africa. New York 1935.

Jehlen M. (1995). "Banned in Concord: Adventures of Huckleberry Finn and Classic American Literature". Ed. F. G. Robinson, The Cambridge Companion to Mark Twain. Cambridge (1995) 93-115.

Kravitz B. (2007). "Reinventing the World and Reinventing the Self in Huck Finn”. Ed. H. Bloom, Bloom's Modern Critical Interpretations: Mark Twain’s Huckleberry Finn. New York (2007) 171-192.

Loux M. J. (2006). Metaphysics: A Contemporary Introduction. New York 2006

Marx L. (1991). “Mr. Eliot, Mr. Trilling, and Huckleberry Finn”. Ed. L. Champion, The Critical Response to Mark Twain's Huckleberry Finn. Westport (1991) 50-60.

Messent P. (2007). The Cambridge Introduction to Mark Twain. Cambridge 2007.

Obenzinger H. (2005). "Going to Tom's Hell in Huckleberry Finn”. Eds. P. Messent \& L. J. Budd, A Companion to Mark Twain. Malden (2005) 401-415.

Pinsker S. (2007). "Huckleberry Finn and the Problem of Freedom”. Ed. H. Bloom. Bloom's Modern Critical Interpretations: Mark Twain's Huckleberry Finn. New York (2007) 67-74.

Railton S. (2004). Mark Twain: A Short Introduction. Malden 2004.

Restad H. E. (2015). American Exceptionalism: An Idea That Made a Nation and Remade the World. New York 2015.

Segal H. G. (2007). "Life without Father: The Role of the Paternal in the Opening Chapters of Huckleberry Finn”. Ed. H. Bloom, Bloom's Modern Critical Interpretations: Mark Twain’s Huckleberry Finn. New York (2007) 27-42.

Schmitz N. (1991). "The Paradox of Liberation in Huckleberry Finn". Ed. L. Champion, The Critical Response to Mark Twain's Huckleberry Finn. Westport (1991) 99-107.

Smith H. N. (1991). "A Sound Heart and A Deformed Conscience”. Ed. L. Champion, The Critical Response to Mark Twain's Huckleberry Finn. Westport (1991) 61-78.

Trachtenberg A. (1991). "The Form of Freedom in The Adventures of Huckleberry Finn”. Ed. L. Champion, The Critical Response to Mark Twain’s Huckleberry Finn. Westport (1991) 87-98.

Trilling L. (2004). "Huckleberry Finn”. Ed. H. Bloom, Bloom's Major Literary Characters: Huck Finn. Philadelphia (2004) 5-16.

Twain M. (1948). The Adventures of Huckleberry Finn. New York 1948.

Wieck C. F. (2007). "Huck and Jim on the Mississippi: Going with the Flow?”. Ed. H. Bloom, Bloom's Modern Critical Interpretations: Mark Twain’s Huckleberry Finn. New York (2007) 43-54. 